\title{
Vitamin D receptor Bsm I polymorphism and osteoporosis risk in postmenopausal women: a meta-analysis from 42 studies
}

Jun Long Liao ${ }^{1 \dagger}$, Qiang Qin², Yong Sheng Zhou', Ru Ping Ma', He Chao Zhou', Mao Rong Gu', Yun Ping Feng ${ }^{1}$, Bo Yuan Wang ${ }^{3^{*}}$ and Ling Yang ${ }^{1 *}$ (D)

\begin{abstract}
Objective: This study aimed to quantitatively summarize the evidence for VDR Bsml gene polymorphism and osteoporosis risk in postmenopausal women.

Materials and methods: The PubMed, EMBASE, Weipu, CNKI, and Wanfang databases were searched for eligible studies. Case-control studies containing available genotype frequencies of B/b were chosen, and odds ratio (OR) with $95 \%$ confidence interval (Cl) was used to assess the strength of this association.

Results: 4485 osteoporosis and 5490 controls were identified in our meta-analysis. In the stratified analysis, a significant association was observed between VDR Bsml gene polymorphism and osteoporosis susceptibility in Caucasians (additive model: $\mathrm{OR}=0.809,95 \% \mathrm{Cl} 0.678 \sim 0.965, p=0.019$; recessive model: $\mathrm{OR}=0.736,95 \% \mathrm{Cl}$ 0.568 0.955, $p=0.021$; and co-dominant model: bb vs. $\mathrm{BB} \mathrm{OR}=0.701,95 \% \mathrm{Cl} 0.511 \sim 0.962 p=0.028$ ), and we failed to find any significant relationship in Asians.

Conclusion: The present meta-analysis suggests that VDR Bsml genotype is associated with increased risk of postmenopausal osteoporosis in Caucasians but not in Asians. To draw comprehensive and true conclusions, further prospective studies with larger numbers of participants worldwide are needed to examine associations between VDR Bsml polymorphism and osteoporosis in postmenopausal women.
\end{abstract}

Keywords: Vitamin D receptor, Bsml polymorphism, Osteoporosis, Postmenopausal, Meta-analysis

\section{Introduction}

Osteoporosis, as a systemic bone disease characterized by decreased bone mineral density, micro-structure deterioration of bone tissue, and increased risk of bone fracture $[1,2]$, is commonly seen in postmenopausal females and aged males; about $30 \%$ of postmenopausal females suffer from osteoporosis [3]. Bone fractures caused by osteoporosis are extremely harmful and are one of the main causes

\footnotetext{
* Correspondence: wby@yxnu.edu.cn; yangling6th@163.com

${ }^{\dagger}$ Junlong Liao and Qiang Qin contributed equally to this work.

${ }^{3}$ The Key Lab of Sports and Rehabilitation, Faculty of Physical Education, Yuxi Normal University, Yuxi 653100, China

'The People's Hospital of Yuxi City, The 6th Affiliated Hospital of Kunming

Medical University, Yuxi 653100, China

Full list of author information is available at the end of the article
}

of disability and death in elderly patients. Research on early identification of high-risk groups has been carried out, which is of substantial clinical significance. The pathogenesis of osteoporosis is currently unclear. It is widely accredited that osteoporosis is related to individual genetic differences, estrogen levels, nutritional status, and lifestyle. In addition, osteoporosis can also be induced by bone formation and bone resorption disorder caused by physical injury, diseases affecting bone metabolism, or long-term use of hormone drugs [4].

The interaction between vitamin $\mathrm{D}$ and its receptor exerts an important role in calcium homeostasis and bone metabolism by regulating osteocyte growth and differentiation, intestinal calcium absorption, and parathyroid hormone secretion [5]. The vitamin D receptor (VDR) gene is

(c) The Author(s). 2020 Open Access This article is licensed under a Creative Commons Attribution 4.0 International License, which permits use, sharing, adaptation, distribution and reproduction in any medium or format, as long as you give appropriate credit to the original author(s) and the source, provide a link to the Creative Commons licence, and indicate if changes were made. The images or other third party material in this article are included in the article's Creative Commons licence, unless indicated otherwise in a credit line to the material. If material is not included in the article's Creative Commons licence and your intended use is not permitted by statutory regulation or exceeds the permitted use, you will need to obtain permission directly from the copyright holder. To view a copy of this licence, visit http://creativecommons.org/licenses/by/4.0/. 
located on chromosome 12 (12q13.1), with a length of more than $100 \mathrm{~kb}$, and more than 100 polymorphic sites are predicted [6, 7]. VDR, therefore, is seen as one of the significant candidate genes to explore the genetic factors leading to osteoporosis. In 1992, Morrison et al. reported that bone mineral density and circulating osteocalcin levels may be affected by VDR BsmI polymorphism (rs1544410) [8, 9].

Postmenopausal osteoporosis, resulting from estrogen deficiency, is the most common type of osteoporosis, and estrogen deficiency results in an increase in bone turnover owing to effects on all types of bone cells [10]. In 1996, Berg et al. reported for the first time that VDR BsmI polymorphism was associated with bone mineral density in postmenopausal females [11]. Since then, epidemiological investigations regarding the assessment of BsmI polymorphism and the susceptibility of postmenopausal osteoporosis have been widely reported. However, the relevant research results have been controversial. For example, in a survey of the Thai population, VDR BsmI polymorphism did not seem to be associated with the risk of postmenopausal osteoporosis [12]. However, significant correlation was observed between VDR genotype and BMD in Chinese postmenopausal females, with bb genotype having the lowest bone density [13]. In recent years, meta-analysis, as a powerful statistical analysis tool, has been adopted to integrate and analyze the data of several published articles; a more accurate and objective assessment is expected to be made on the research results and to explain the heterogeneity between these results [14]. Therefore, the meta-analysis was performed on the currently published eligible casecontrol studies combined with the previous research results, and the relationship between Bsm I polymorphism and the risk of osteoporosis in postmenopausal females was also explored.

\section{Methods}

\section{Literature search}

PubMed (http://www.ncbi.nlm.nih.gov/pubmed), EMBASE (http://www.embase.com), Weipu (http://www.cqvip.com/), CNKI (http://www.cnki.net/), and Wanfang (http://g.wanfangdata.com.cn/) databases were thoroughly searched by the authors (last search update, July 10, 2020). The keywords were "vitamin D receptor" or "VDR" and "osteoporosis" or "fracture" and "BsmI" or "rs1544410" in combination with "genetic" or "polymorphism" or "variant".

\section{Inclusion criteria}

Selection criteria of this meta-analysis are listed as follows: (1) case-control or cohort studies, (2) participants included postmenopausal women, (3) assessment of the relationship of BsmI and osteoporosis or fracture, (4) containing available genotype frequencies of BsmI, (5) provided BMD values (mean and standard deviation) of lumbar spine and femoral neck, osteoporosis was defined as $\mathrm{BMD} \leq-2.5 \mathrm{SDs}$ (T-score).

\section{Exclusion criteria}

Exclusion criteria of this meta-analysis are listed as follows: (1) reviews, case reports, comments, and letters; (2) incomplete data; (3) without full text. In addition, all relevant references were also reviewed. If there were duplicate data in papers published by the same author, only the most recent or complete study was included in this analysis.

\section{Data extraction}

Two independent investigators extracted data from eligible studies; the characteristics included the following: (1) the 1st author, (2) publication year, (3) region, (4) ethnicity, (5) age range, (6) sample size, (7) allele frequency of cases and controls, and (8) genotyping method. Any different evaluation results need to be revisited until a consensus is reached.

\section{Quality assessment}

The quality of eligible publications was assessed by the Newcastle-Ottawa quality assessment scales (NOS) [15]. The scale contains three parts: the selection of groups (4 questions, 1 score each), the comparability of groups (1 question, 2 scores), the ascertainment of exposure (3 questions, 1 score each). The scores $\geq 5$ were regarded as a high-quality study.

\section{Statistics analysis}

The observed genotype frequencies of the VDR BsmI polymorphism in control groups were assessed for Hardy-Weinberg equilibrium using the $X^{2}$ test. The gene frequencies of the control group must conform to the Hardy-Weinberg equilibrium $(p>0.05)$. The relationship between VDR BsmI gene and osteoporosis was accessed by calculating odds ratios (ORs) and 95\% confidence intervals (CIs). The pooled ORs were performed for additive genetic model (b vs. $\mathrm{B})$, dominant model $(\mathrm{bb}+$ $\mathrm{Bb}$ vs. $\mathrm{BB}$ ), recessive model (bb vs. $\mathrm{Bb}+\mathrm{BB}$ ), and co-dominant model (Bb vs. $\mathrm{BB}$, bb vs. $\mathrm{BB}$ ) respectively. The subgroup analyses by ethnic groups were also performed. The statistically significant $p$ value was set at 0.05 . Heterogeneity assumption was evaluated by a chisquare-based $Q$ test $(p<0.05$ indicated heterogeneity across studies). The summary OR estimate of each study was calculated by the fixed-effects model if there was no significant heterogeneity. Otherwise, the random-effects model was used $[16,17]$. The potential for publication bias was examined by a Begg's test (funnel plot method, $p<0.05$ considered representative of statistical significance) [18]. All analyses were performed by the Stata software (version 11.0). 


\section{Results}

\section{Eligible studies}

Literature screening process is shown in Fig. 1. Based on the pre-established search strategy, 42 studies were finally enrolled for integrated analyses, including 4485 osteoporosis and 5490 controls. Twenty-three studies [19-46] were performed in Caucasians, and 9 studies [12, 13, 47-53] were subsumed into Asians. In addition, 2 interracial studies [32, 54] were conducted in mixed race. The main characteristics of the selected studies are listed in Table 1. According to the NOS for assessing the quality of case-control studies, all the selected articles meet the requirements (the scores $\geq 5$, Table 2). The observed genotype frequencies of the VDR BsmI polymorphism in each control group were assessed by Hardy-Weinberg equilibrium (Table 3), and 11 unequal studies were excluded [20, 25, 27, 33, 36-39, 46, 47, 53].

\section{Meta-analysis}

Differences in allelic distribution by ethnicity could be partially responsible for the observed differences in the association between VDR BsmI and osteoporosis. The evaluations of the association between VDR Bsml polymorphism and osteoporosis risk in postmenopausal women are summarized in Table 4. The overall results suggested that there was no association between BsmI polymorphism and the risk of osteoporosis in all genetic models. In the subgroup analysis based on ethnicity, the included studies were divided into Asian, Caucasian, and mix populations. The results showed that VDR BsmI polymorphism was significantly associated with the risk of postmenopausal osteoporosis in Caucasian populations (additive model: OR 0.809, 95\% CI 0.678 0.965, $p$ $=0.019$; recessive model: OR 0.736, 95\% CI 0.568 0.955, $p=0.021$; and co-dominant model: bb vs. BB OR 0.701, 95\% CI $0.511 \sim 0.962, p=0.028$, Fig. 2). However, no significant association was found in any genetic models in both Asian and mix populations.

\section{Publication bias}

Begg's test was performed to quantitatively evaluate the publication bias of literatures on osteoporosis. The results provided statistical evidence in overall results, suggesting the absence of publication bias. All graphical funnel plots of the included studies appeared to be symmetrical. There was no visual evidence of publication bias visually from the funnel plot, which implied that the publication bias was low in the present overall meta-analysis (b vs. BB: $p=$ 0.856 ; b/b vs. Bb/BB: $p=0.851$; $\mathrm{Bb} / \mathrm{bb}$ vs. $\mathrm{BB}: p=0.813$; $\mathrm{Bb}$ vs. $\mathrm{BB}: p=0.510$; bb vs. $\mathrm{BB} p=0.937)$.

\section{Discussion}

Genetic difference is one important factor affecting the susceptibility to osteoporosis. VDR gene has been widely studied because of its important role in regulating bone metabolism and bone homeostasis. The VDR Bsml polymorphism is located in the $3^{\prime}$ untranslated region (UTR). It is involved in regulating the stability of VDR mRNA and is one of the most important subtypes of VDR gene polymorphism. Studies on VDR Bsml polymorphism and

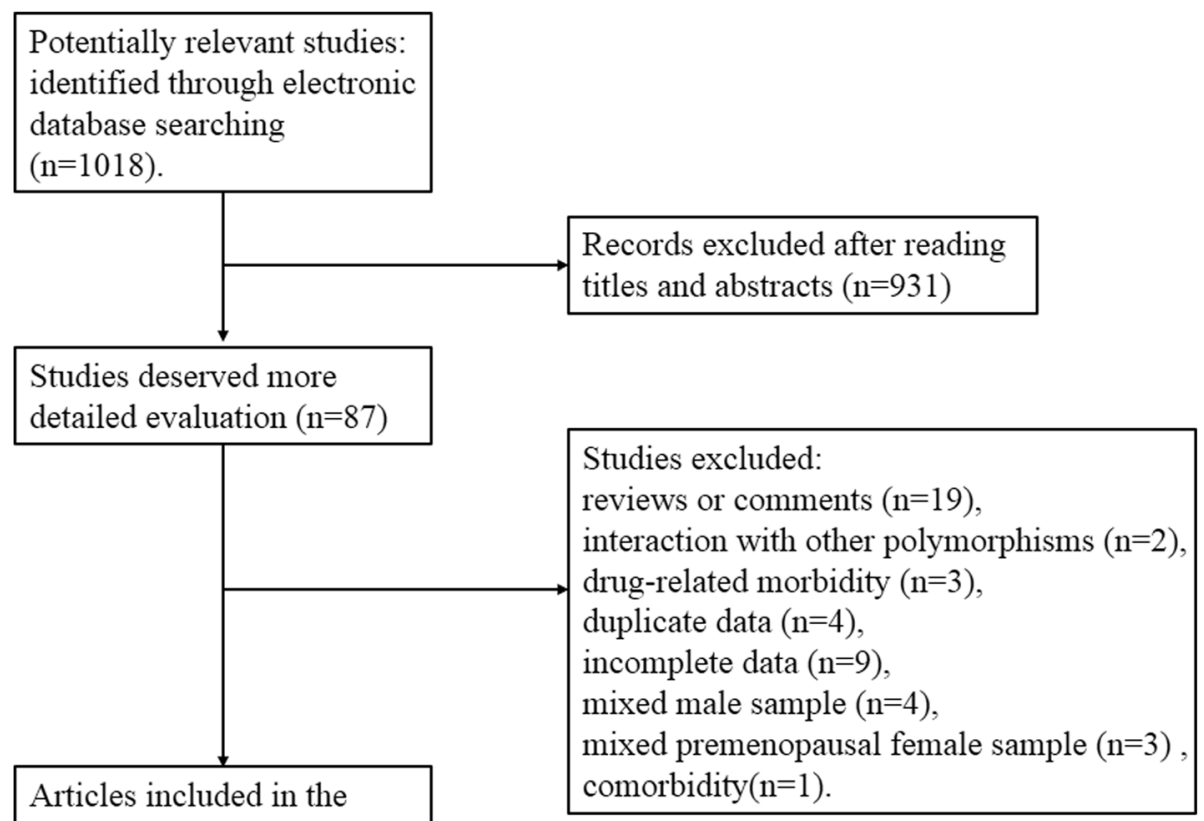

Fig. 1 Flow chart indicating search results 


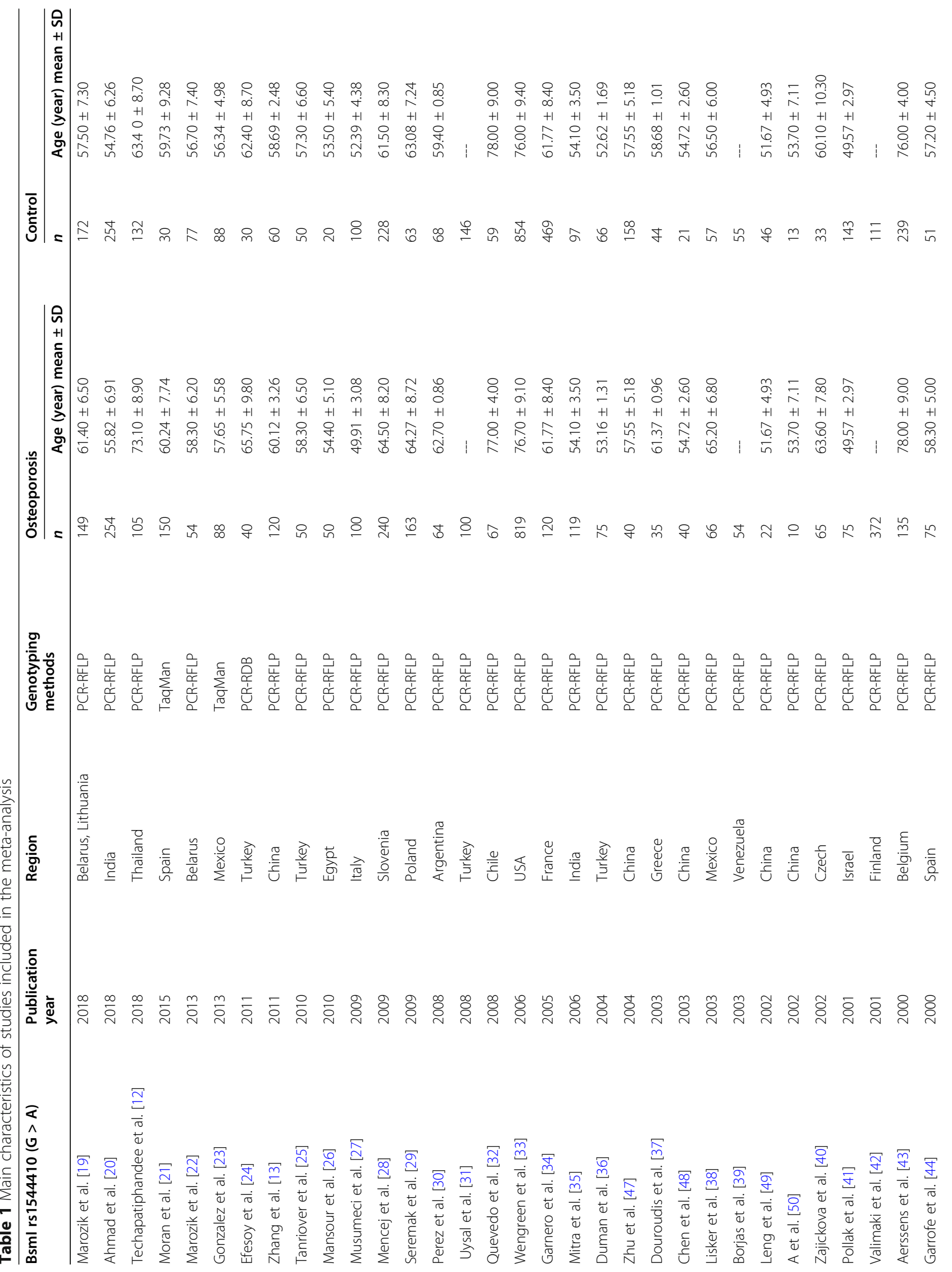




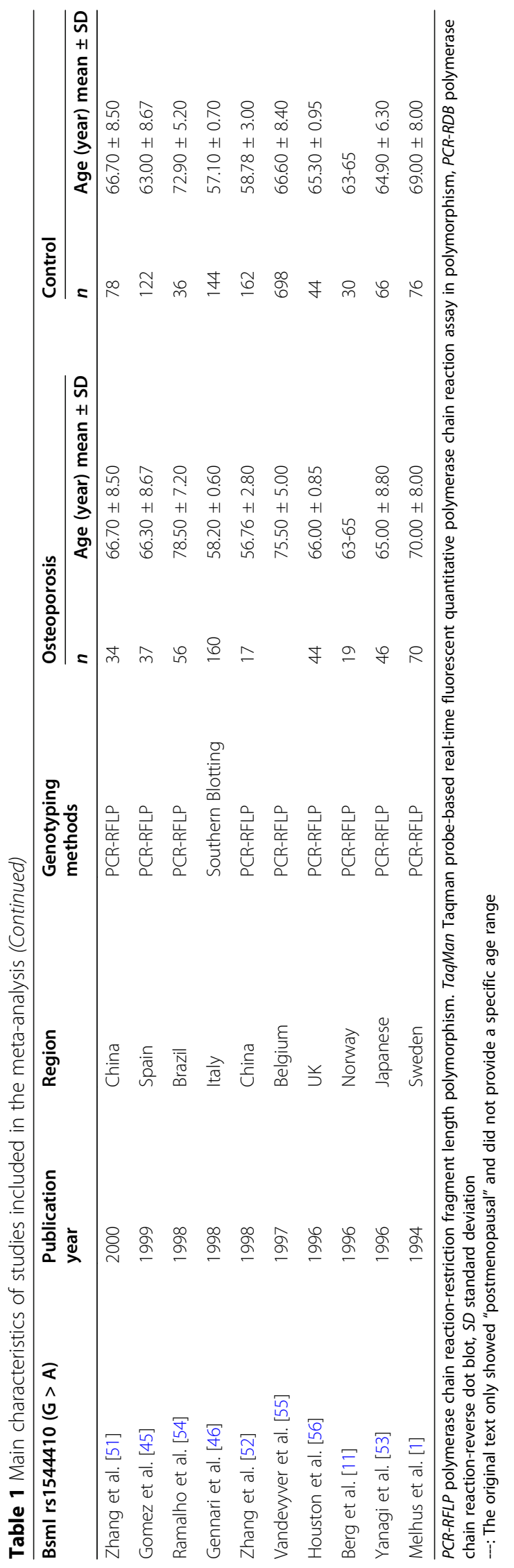




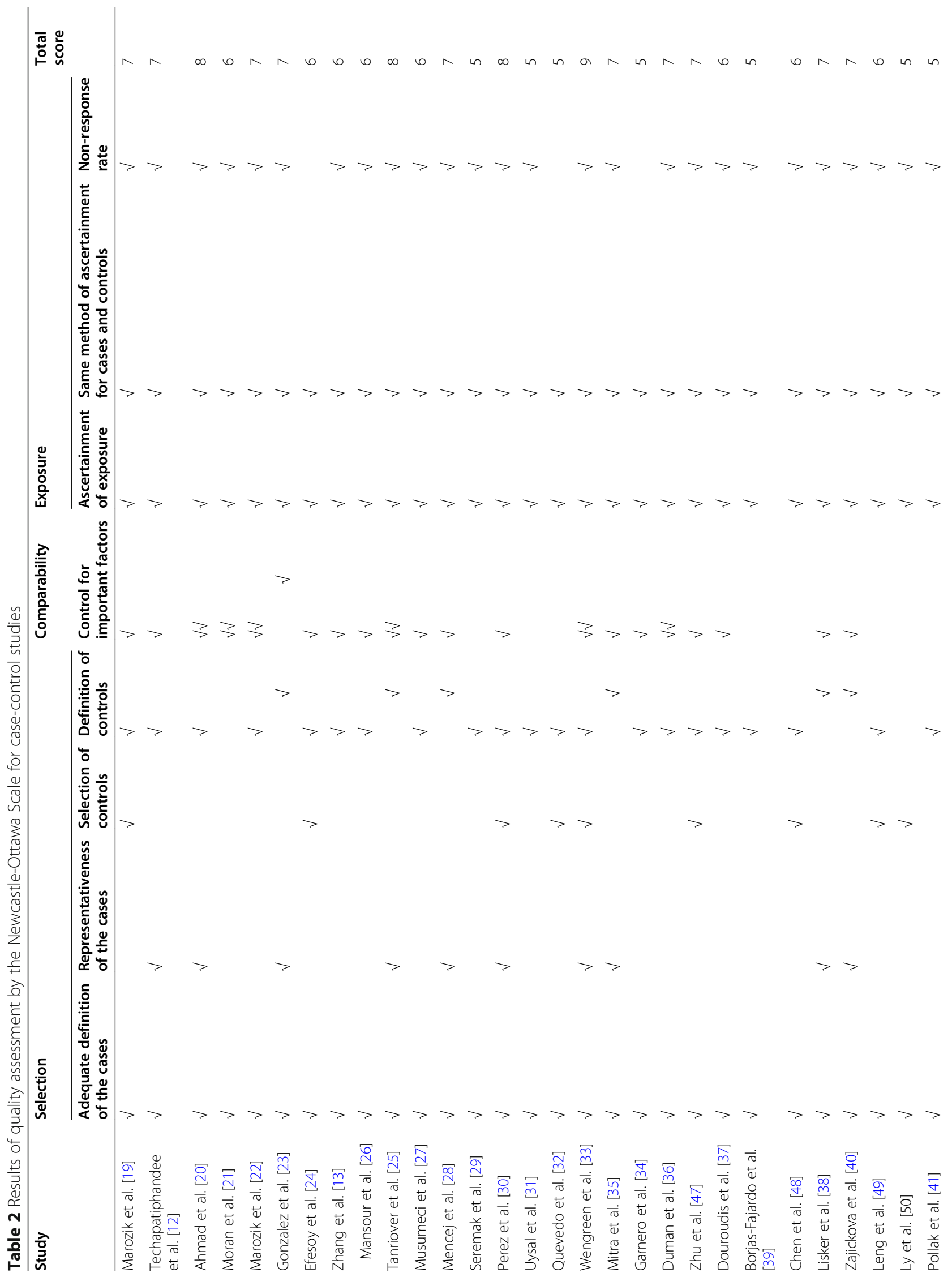




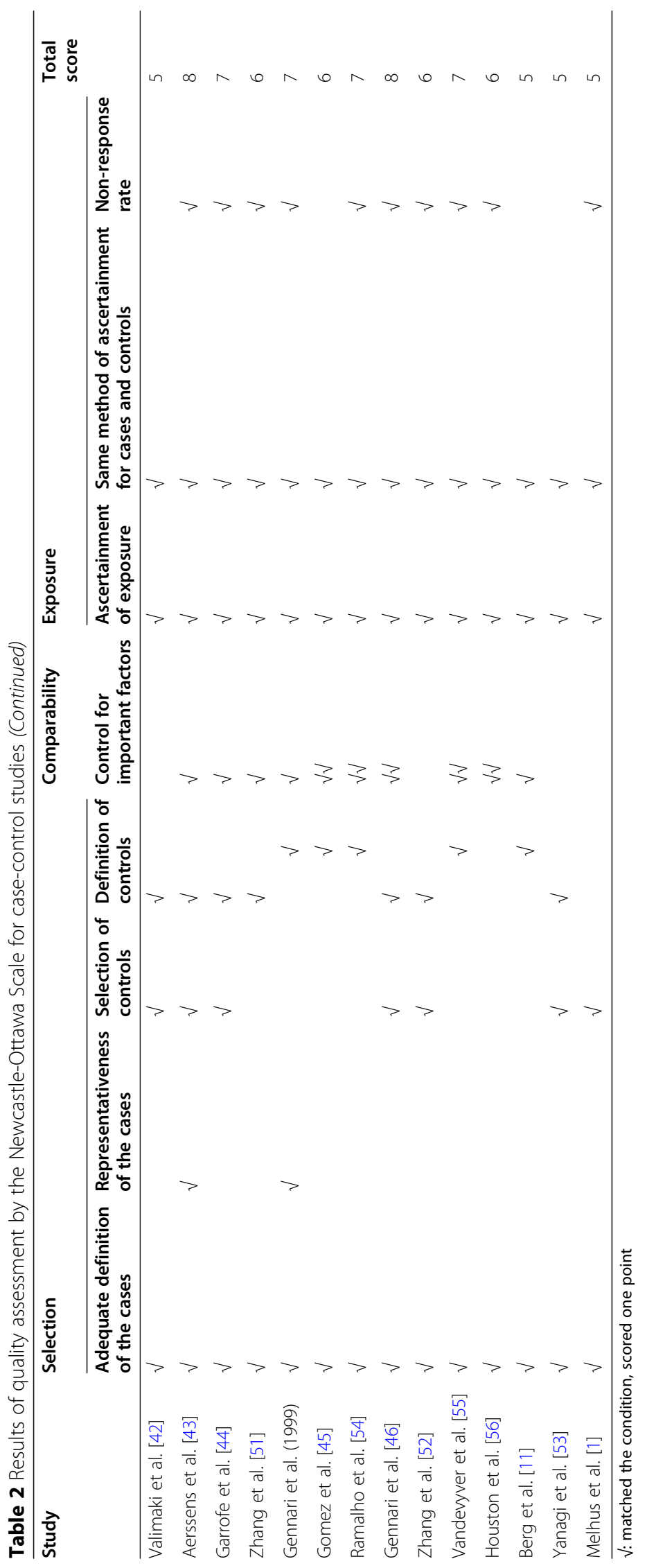


Table 3 The distribution of VDR Bsml genotypes for postmenopausal osteoporosis and controls

\begin{tabular}{|c|c|c|c|c|c|c|c|c|c|}
\hline \multirow[t]{2}{*}{ Bsml rs1544410 (G > A) } & \multirow{2}{*}{$\begin{array}{l}\text { Publication } \\
\text { year }\end{array}$} & \multirow[t]{2}{*}{ Ethnicity } & \multicolumn{3}{|c|}{ Osteoporosis } & \multicolumn{3}{|c|}{ Control } & \multirow[t]{2}{*}{$p^{\mathrm{a}}$} \\
\hline & & & BB & $\mathrm{Bb}$ & bb & BB & $\mathrm{Bb}$ & $\mathbf{b b}$ & \\
\hline Marozik et al. [19] & 2018 & Caucasian & 53 & 64 & 32 & 35 & 73 & 64 & 0.098 \\
\hline Ahmad et al. [20] & 2018 & Caucasian & 54 & 137 & 63 & 54 & 152 & 48 & 0.002 \\
\hline Moran et al. [21] & 2015 & Caucasian & 18 & 65 & 67 & 3 & 19 & 8 & 0.097 \\
\hline Marozik et al. [22] & 2013 & Caucasian & 12 & 31 & 11 & 11 & 26 & 40 & 0.061 \\
\hline Gonzalez et al. [23] & 2013 & Caucasian & 54 & 28 & 6 & 46 & 38 & 4 & 0.267 \\
\hline Efesoy et al. [24] & 2011 & Caucasian & 5 & 23 & 12 & 5 & 15 & 10 & 0.876 \\
\hline Tanriover et al. [25] & 2010 & Caucasian & 15 & 19 & 16 & 19 & 7 & 24 & $<0.001$ \\
\hline Mansour et al. [26] & 2010 & Caucasian & 27 & 15 & 8 & 1 & 2 & 17 & 0.050 \\
\hline Musumeci et al. [27] & 2009 & Caucasian & 30 & 55 & 15 & 13 & 60 & 27 & 0.025 \\
\hline Mencej et al. [28] & 2009 & Caucasian & 103 & 110 & 27 & 88 & 100 & 40 & 0.215 \\
\hline Seremak et al. [29] & 2009 & Caucasian & 27 & 66 & 70 & 10 & 27 & 26 & 0.506 \\
\hline Perez et al. [30] & 2008 & Caucasian & 17 & 35 & 12 & 20 & 32 & 16 & 0.647 \\
\hline Uysal et al. [31] & 2008 & Caucasian & 18 & 48 & 34 & 24 & 78 & 44 & 0.283 \\
\hline Quevedo et al. [32] & 2008 & Caucasian & 11 & 46 & 10 & 9 & 37 & 13 & 0.050 \\
\hline Wengreen et al. [33] & 2006 & Caucasian & 154 & 393 & 272 & 140 & 376 & 338 & 0.043 \\
\hline Garnero et al. [34] & 2005 & Caucasian & 25 & 62 & 33 & 65 & 224 & 180 & 0.724 \\
\hline Mitra et al. [35] & 2006 & Caucasian & 51 & 46 & 22 & 19 & 38 & 40 & 0.080 \\
\hline Duman et al. [36] & 2004 & Caucasian & 18 & 54 & 3 & 17 & 42 & 7 & 0.014 \\
\hline Douroudis et al. [37] & 2003 & Caucasian & 3 & 12 & 20 & 10 & 29 & 5 & 0.026 \\
\hline Lisker et al. [38] & 2003 & Caucasian & 15 & 17 & 34 & 13 & 38 & 6 & 0.008 \\
\hline Borjas et al. [39] & 2003 & Caucasian & 28 & 20 & 6 & 11 & 36 & 8 & 0.020 \\
\hline Zajickova et al. [40] & 2002 & Caucasian & 21 & 24 & 20 & 10 & 13 & 10 & 0.223 \\
\hline Pollak et al. [41] & 2001 & Caucasian & 13 & 38 & 24 & 16 & 67 & 60 & 0.675 \\
\hline Valimaki et al. [42] & 2001 & Caucasian & 44 & 175 & 153 & 20 & 55 & 36 & 0.899 \\
\hline Aerssens et al. [43] & 2000 & Caucasian & 26 & 60 & 49 & 52 & 125 & 62 & 0.459 \\
\hline Garrofe et al. [44] & 2000 & Caucasian & 9 & 49 & 17 & 10 & 22 & 19 & 0.434 \\
\hline Gomez et al. [45] & 1999 & Caucasian & 7 & 20 & 10 & 20 & 51 & 51 & 0.241 \\
\hline Gennari et al. [46] & 1998 & Caucasian & 40 & 92 & 28 & 11 & 76 & 57 & 0.035 \\
\hline Vandevyver et al. [55] & 1997 & Caucasian & 12 & 50 & 24 & 127 & 368 & 203 & 0.076 \\
\hline Houston et al. [56] & 1996 & Caucasian & 8 & 19 & 17 & 9 & 19 & 16 & 0.450 \\
\hline Berg et al. [11] & 1996 & Caucasian & 4 & 8 & 7 & 8 & 11 & 11 & 0.156 \\
\hline Melhus et al. [1] & 1994 & Caucasian & 14 & 29 & 27 & 7 & 35 & 34 & 0.637 \\
\hline Techapatiphandee et al. [12] & 2018 & Asian & 85 & 19 & 1 & 103 & 25 & 4 & 0.123 \\
\hline Zhang et al. [13] & 2011 & Asian & 9 & 25 & 86 & 16 & 36 & 8 & 0.086 \\
\hline Zhu et al. [47] & 2004 & Asian & 6 & 26 & 8 & 7 & 105 & 46 & $<0.001$ \\
\hline Chen et al. [48] & 2003 & Asian & 0 & 7 & 33 & 0 & 3 & 18 & 0.724 \\
\hline Leng et al. [49] & 2002 & Asian & 0 & 11 & 11 & 7 & 19 & 20 & 0.488 \\
\hline Ly et al. [50] & 2002 & Asian & 0 & 4 & 6 & 1 & 5 & 7 & 0.935 \\
\hline Zhang et al. [51] & 2000 & Asian & 2 & 15 & 17 & 7 & 36 & 35 & 0.598 \\
\hline Zhang et al. [52] & 1998 & Asian & 0 & 3 & 14 & 0 & 14 & 148 & 0.565 \\
\hline
\end{tabular}


Table 3 The distribution of VDR Bsml genotypes for postmenopausal osteoporosis and controls (Continued)

\begin{tabular}{|c|c|c|c|c|c|c|c|c|c|}
\hline \multirow[t]{2}{*}{ Bsml rs1544410 (G > A) } & \multirow{2}{*}{$\begin{array}{l}\text { Publication } \\
\text { year }\end{array}$} & \multirow[t]{2}{*}{ Ethnicity } & \multicolumn{3}{|c|}{ Osteoporosis } & \multicolumn{3}{|c|}{ Control } & \multirow[t]{2}{*}{$p^{a}$} \\
\hline & & & BB & $\mathrm{Bb}$ & bb & BB & $\mathrm{Bb}$ & bb & \\
\hline Yanagi et al. [53] & 1996 & Asian & 12 & 12 & 22 & 2 & 7 & 57 & 0.013 \\
\hline Ramalho et al. [54] & 1998 & $\operatorname{mix}$ & 13 & 23 & 20 & 7 & 11 & 18 & 0.050 \\
\hline Quevedo et al. [32] & 2008 & $\operatorname{mix}$ & 11 & 46 & 10 & 9 & 37 & 13 & 0.050 \\
\hline
\end{tabular}

The bold values emphasize that the data does not conform to the Hardy-Weinberg equilibrium, to facilitate the readers to scan the content

${ }^{a} p$ value for Hardy-Weinberg equilibrium in the control group

susceptibility to osteoporosis are various, but the results are not consistent. A recent meta-analysis [57] shows that VDR BsmI is associated with an increased risk of postmenopausal osteoporosis in Asians, while in Caucasians seem to be unrelated, which is contrary to the results of two previously published studies $[58,59]$. Since the previous metaanalysis only involved genetic association studies published before 2015, the combination of different original data in each study might have a great impact on the mixed distribution of genotypes. So introducing new data to update meta-analysis is necessary. Through our meta-analysis, it has been found that the VDR Bsml gene polymorphism generally seems not to be a susceptibility gene for postmenopausal osteoporosis. However, in the subgroup analysis, BsmI polymorphism was found to be associated with the risk of postmenopausal osteoporosis in Caucasians, which was not found in the previous meta-analysis. In Asian postmenopausal women, there was no obvious relationship between Bsml polymorphism and osteoporosis susceptibility, which was consistent with the results of a previous metaanalysis of the Chinese population [60]. Through sensitivity analysis and publication bias detection, the results of this meta-analysis were true and credible. The original data of all published eligible studies were almost covered by this meta-analysis. However, according to a recently published meta-analysis of Yadav et al. [61], in the absence of a subgroup analysis based on the sex and age of patients or the type of osteoporosis, BsmI polymorphism seemed not to be associated with the pathogenesis of osteoporosis. It indicated that possible relationship between VDR gene polymorphisms and osteoporosis may be related to gender, race, and age difference of subjects. There may be different

Table 4 ORs and 95\% Cl for postmenopausal osteoporosis and the VDR Bsml polymorphism under different genetic models

\begin{tabular}{|c|c|c|c|c|}
\hline Genetic model & Population & Pooled OR $[95 \% \mathrm{Cl}] p$ & $\begin{array}{l}\text { Heterogeneity } \\
p \text { value* }\end{array}$ & $\begin{array}{l}\text { Publication bias } \\
\text { Begg's test } p \text { value }\end{array}$ \\
\hline \multirow[t]{4}{*}{ Additive (b vs. B) } & Caucasian & $0.809[0.678 \sim 0.965] \mathbf{0 . 0 1 9}$ & $<0.001$ & 0.893 \\
\hline & Asian & $1.353[0.628 \sim 2.915] 0.440$ & $<0.001$ & 0.881 \\
\hline & Mix & 0.778 [0.530 1.144] 0.202 & 0.594 & 0.317 \\
\hline & overall & 0.880 [0.729 1.063] 0.185 & $<0.001$ & 0.856 \\
\hline \multirow[t]{4}{*}{ Recessive (bb vs. Bb/BB) } & Caucasian & $0.736[0.568 \sim 0.955] \mathbf{0 . 0 2 1}$ & $<0.001$ & 0.853 \\
\hline & Asian & $1.340[0.442 \sim 4.061] 0.605$ & $<0.001$ & 0.652 \\
\hline & Mix & $0.585[0.314 \sim 1.090] 0.091$ & 0.862 & 0.317 \\
\hline & overall & 0.813 [0.619 1.066] 0.134 & $<0.001$ & 0.815 \\
\hline \multirow[t]{4}{*}{ Dominant (Bb/bb vs. BB) } & Caucasian & $0.810[0.654 \sim 1.004] 0.055$ & 0.009 & 0.833 \\
\hline & Asian & 2.107 [0.768 5.784] 0.148 & 0.033 & 0.806 \\
\hline & Mix & $0.860[0.426 \sim 1.736] 0.673$ & 0.848 & 1 \\
\hline & overall & 0.884 [0.715 1.092] 0.253 & 0.001 & 0.813 \\
\hline \multirow[t]{4}{*}{ Bb vs. BB } & Caucasian & $0.880[0.754 \sim 1.027] 0.105$ & 0.427 & 0.579 \\
\hline & Asian & 1.206 [0.738 1.969] 0.455 & 0.627 & 0.117 \\
\hline & Mix & $1.061[0.501 \sim 2.248] 0.878$ & 0.896 & 0.317 \\
\hline & overall & 0.911 [0.788 1.053] 0.206 & 0.615 & 0.510 \\
\hline \multirow[t]{4}{*}{ bb vs. BB } & Caucasian & $0.701[0.511 \sim 0.962] \mathbf{0 . 0 2 8}$ & $<0.001$ & 0.895 \\
\hline & Asian & $3.146[0.566 \sim 17.50] 0.190$ & 0.007 & 0.117 \\
\hline & Mix & $0.612[0.270 \sim 1.391] 0.241$ & 0.952 & 0.317 \\
\hline & overall & $0.811[0.576 \sim 1.141] 0.228$ & $<0.001$ & 0.937 \\
\hline
\end{tabular}



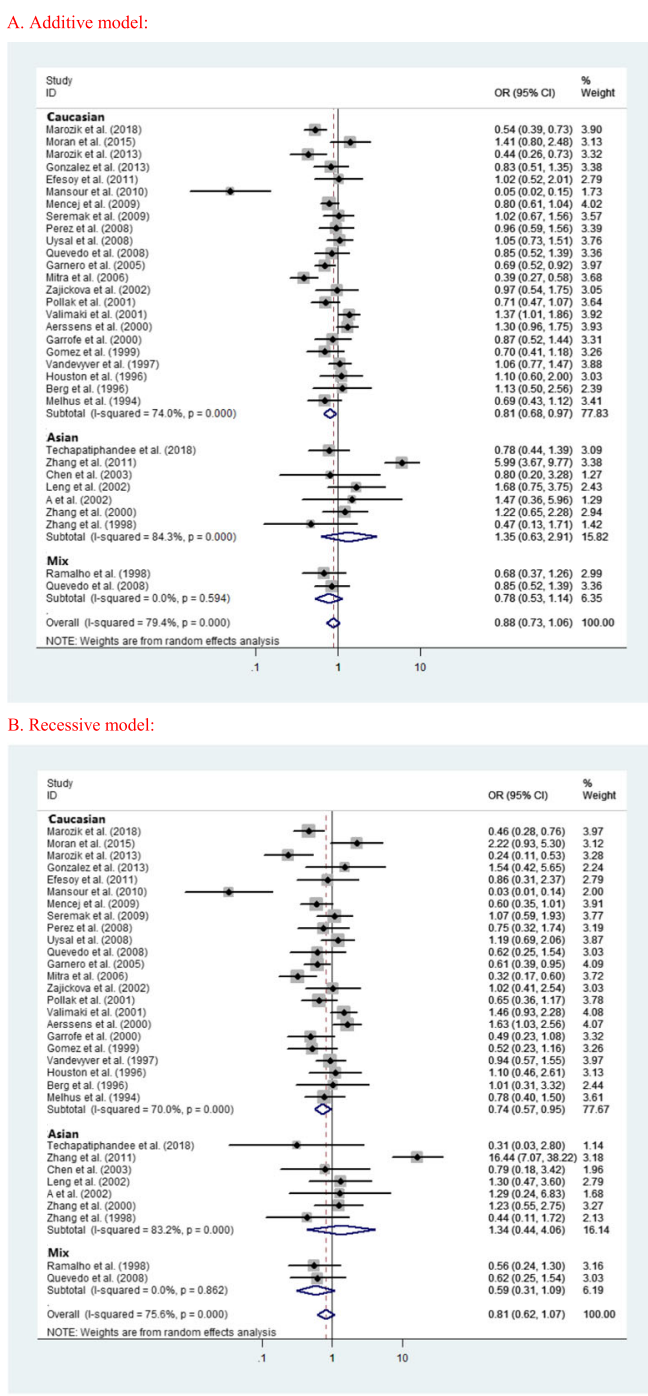

C. Co-dominant model (bb vs. BB)

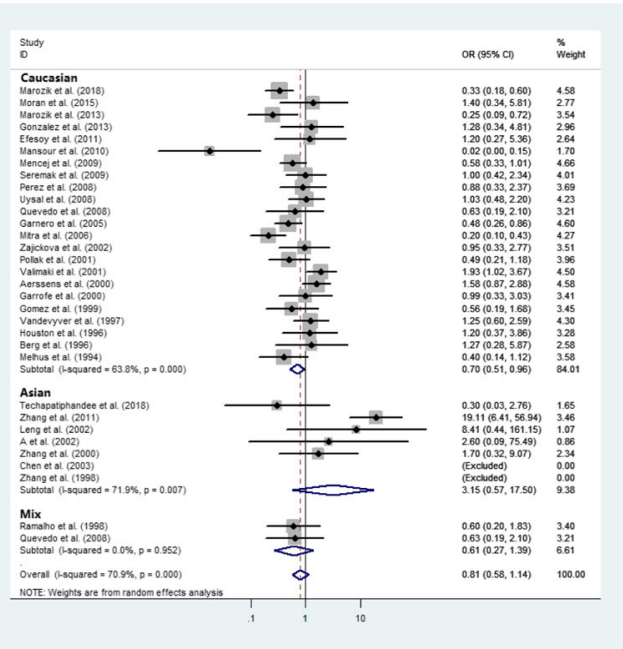

Fig. 2 Association of VDR Bsml polymorphism under different genetic models with osteoporosis risk in postmenopausal women. a Additive model. b Recessive model. c Co-dominant model (bb vs. BB)

mechanisms of VDR gene polymorphisms on different types of osteoporosis [62]. Our research also verified this point, and it should be regarded as a valuable supplement to the published related studies. The causes of osteoporosis are complex; in addition to the joint effects of multi-gene regulation, environmental factors and lifestyles also play an important role [63]. This meta-analysis only discussed genetic factors in the original literature, and the interaction of other factors such as dietary calcium and light exposure and VDR gene polymorphisms on osteoporosis was uninvolved. Therefore, referring to the analysis methods of other researchers [64], we focused on checking the details of the dietary habits of the participants in each study and determined that there was no difference in calcium intake between the case-control group. We believe that for more accurate evaluation of the relationship between vitamin D receptor gene polymorphism and postmenopausal osteoporosis, researches having large samples are required, and the synergy of other factors such as diet, environment, and exercise should be considered more comprehensively when cases are included in the group.

\section{Conclusions}

In conclusion, our study believes that VDR BsmI polymorphism and postmenopausal osteoporosis are genetically linked in Caucasians, but not in Asians. It is necessary to conduct large-scale studies to verify the correlation of different populations and environmental factors in the susceptibility to osteoporosis.

\section{Acknowledgements \\ Not applicable}

\section{Authors' contributions}

Ling Yang and Boyuan Wang conceived and designed this meta-analysis. Qiang Qin, Yongsheng Zhou, and Hechao Zhou searched literatures. Maorong Gu and Yunping Feng typed data entry in the tables. Junlong Liao and Ruping Ma performed analysis. Ling Yang and Boyuan Wang wrote the manuscript. All authors have approved the final manuscript as submitted.

\section{Funding}

This work was supported by the Yuxi Social Science Foundation (YXSK226).

\section{Availability of data and materials \\ Not applicable.}

Ethics approval and consent to participate

Not applicable.

Consent for publication

Not applicable.

Competing interests

The authors declare that they have no competing interests. 


\section{Author details}

${ }^{1}$ The People's Hospital of Yuxi City, The 6th Affiliated Hospital of Kunming Medical University, Yuxi 653100, China. ${ }^{2}$ The Sports Department, Zhejiang University of Science \& Technology, Hangzhou 310023, China. ${ }^{3}$ The Key Lab of Sports and Rehabilitation, Faculty of Physical Education, Yuxi Normal University, Yuxi 653100, China.

Received: 1 September 2020 Accepted: 6 November 2020

Published online: 25 November 2020

\section{References}

1. Melhus $H$, Kindmark A, Amer $S$, et al. Vitamin D receptor genotypes in osteoporosis. Lancet (London, England). 1994;344:2.

2. Kanis JA, Melton $L J$ 3rd, Christiansen C, et al. The diagnosis of osteoporosis. J Bone Miner Res. 1994;9(8):1137-41. https://doi.org/10.1002/jbmr. 5650090802 published Online First: 1994/08/01.

3. Lane NE. Epidemiology, etiology, and diagnosis of osteoporosis. Am J Obstet Gynecol. 2006;194(2 Suppl):S3-11. https://doi.org/10.1016/j.ajog.2005 08.047 published Online First: 2006/02/02.

4. $\quad$ Lamichhane AP. Osteoporosis-an update. JNMA J Nepal Med Assoc 2005; 44(158):60-6. [published Online First: 2006/03/30].

5. Williams FM, Spector TD. The genetics of osteoporosis. Acta Reumatol Port 2007;32(3):231-40. [published Online First: 2007/10/18].

6. Horst-Sikorska W, Dytfeld J, Wawrzyniak A, et al. Vitamin D receptor gene polymorphisms, bone mineral density and fractures in postmenopausal women with osteoporosis. Mol Biol Rep 2013;40(1):383-90. doi: https://doi. org/10.1007/s11033-012-2072-3 [published Online First: 2012/10/17].

7. Dennison EM, Arden NK, Keen RW, et al. Birthweight, vitamin D receptor genotype and the programming of osteoporosis. Paediatr Perinat Epidemiol 2001;15(3):211-9. [published Online First: 2001/08/08].

8. Morrison NA, Yeoman R, Kelly PJ, et al. Contribution of trans-acting factor alleles to normal physiological variability: vitamin $D$ receptor gene polymorphism and circulating osteocalcin. Proc Natl Acad Sci U S A 1992; 89(15):6665-9. doi: https://doi.org/10.1073/pnas.89.15.6665 [published Online First: 1992/08/01]

9. Morrison NA, Qi JC, Tokita A, et al. Prediction of bone density from vitamin D receptor alleles. Nature 1994;367(6460):284-7. doi: https://doi.org/10.1038/ 367284a0 [published Online First: 1994/01/20].

10. Eastell R, O'Neill TW, Hofbauer LC, et al. Postmenopausal osteoporosis. Nat Rev Dis Primers 2016;2:16069. doi: https://doi.org/10.1038/nrdp.2016.69 [published Online First: 2016/09/30].

11. Berg JP, Falch JA, Haug E. Fracture rate, pre- and postmenopausal bone mass and early and late postmenopausal bone loss are not associated with vitamin D receptor genotype in a high-endemic area of osteoporosis. Eur J Endocrinol 1996;135(1):96-100. [published Online First: 1996/07/01].

12. Techapatiphandee M, Tammachote $N$, Tammachote $R$, et al. VDR and TNFS F11 polymorphisms are associated with osteoporosis in Thai patients. Biomed Rep 2018;9(4):350-56. doi: https://doi.org/10.3892/br.2018.1137 [published Online First: 2018/09/21].

13. Zhang H, Su PJ, Chen GF, et al. Relationship between vitamin D receptor gene polymorphism and bone mineral density and traditional Chinese medicine differentiation type in postmenopausal women in Zhongshan area of Guangdong. Chin J Tradit Med Traumatol Orthop 2011;19(2):3. [published Online First: 21].

14. Nakagawa S, Noble DW, Senior AM, et al. Meta-evaluation of meta-analysis: ten appraisal questions for biologists. BMC Biol 2017;15(1):18. doi: https:// doi.org/10.1186/s12915-017-0357-7 [published Online First: 2017/03/05].

15. Stang A. Critical evaluation of the Newcastle-Ottawa scale for the assessment of the quality of nonrandomized studies in meta-analyses. Eur J Epidemiol 2010;25(9):603-5. doi: https://doi.org/10.1007/s10654-010-9491-z [published Online First: 2010/07/24].

16. Mantel N, Haenszel W. Statistical aspects of the analysis of data from retrospective studies of disease. J Natl Cancer Inst 1959;22(4):719-48. [published Online First: 1959/04/01].

17. DerSimonian R, Laird N. Meta-analysis in clinical trials. Control Clin Trials 1986;7(3):177-88. [published Online First: 1986/09/01].

18. Egger M, Davey Smith $G$, Schneider M, et al. Bias in meta-analysis detected by a simple, graphical test. BMJ 1997;315(7109):629-34. doi: https://doi.org/ 10.1136/bmj.315.7109.629 [published Online First: 1997/10/06].

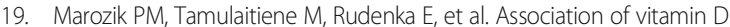
receptor gene variation with osteoporosis risk in Belarusian and Lithuanian postmenopausal women. Front Endocrinol (Lausanne) 2018;9:305. doi: https:// doi.org/10.3389/fendo.2018.00305 [published Online First: 2018/06/21].

20. Ahmad I, Jafar T, Mahdi F, et al. Association of vitamin D receptor (Fokl and Bsml) gene polymorphism with bone mineral density and their effect on 25-hydroxyvitamin D level in North Indian postmenopausal women with osteoporosis. Indian J Clin Biochem 2018;33(4):429-37. doi: https://doi.org/ 10.1007/s12291-017-0706-x [published Online First: 2018/10/16].

21. Moran JM, Pedrera-Canal M, Rodriguez-Velasco FJ, et al. Lack of association of vitamin D receptor Bsml gene polymorphism with bone mineral density in Spanish postmenopausal women. PeerJ 2015;3:e953. doi: https://doi.org/ 10.7717/peerj.953 [published Online First: 2015/07/15].

22. Marozik P, Mosse I, Alekna $V$, et al. Association between polymorphisms of VDR, COL1A1, and LCT genes and bone mineral density in Belarusian women with severe postmenopausal osteoporosis. Medicina (Kaunas) 2013; 49(4):177-84. [published Online First: 2013/08/30].

23. Gonzalez-Mercado A, Sanchez-Lopez JY, Regla-Nava JA, et al. Association analysis of vitamin $D$ receptor gene polymorphisms and bone mineral density in postmenopausal Mexican-Mestizo women. Genet Mol Res 2013;12(3):2755-63. doi: https://doi.org/10.4238/2013.July.30.13 [published Online First: 2013/08/28].

24. Efesoy A. Relationship of the vitamin D receptor and collagen la1 gene polymorphisms with low bone mineral density and vertebral fractures in postmenopausal Turkish women. Turkish Journal of Rheumatology. 2011; 26(4):295-302. https://doi.org/10.5606/tjr.2011.047.

25. Durusu Tanriover M, Bora Tatar G, Uluturk TD, et al. Evaluation of the effects of vitamin D receptor and estrogen receptor 1 gene polymorphisms on bone mineral density in postmenopausal women. Clin Rheumatol 2010; 29(11):1285-93. doi: https://doi.org/10.1007/s10067-010-1548-6 [published Online First: 2010/08/11]

26. Mansour L, Sedky M, AbdelKhader M, et al. The role of vitamin D receptor genes (FOKI and BSMI) polymorphism in osteoporosis. Middle East Fertility Society Journal. 2010;15(2):79-83. https://doi.org/10.1016/j.mefs.2010.05.002.

27. Musumeci M, Vadala G, Tringali G, et al. Genetic and environmental factors in human osteoporosis from Sub-Saharan to Mediterranean areas. J Bone Miner Metab 2009;27(4):424-34. doi: https://doi.org/10.1007/s00774-0090041-2 [published Online First: 2009/03/04].

28. Mencej-Bedrac S, Prezelj J, Kocjan T, et al. The combinations of polymorphisms in vitamin D receptor, osteoprotegerin and tumour necrosis factor superfamily member 11 genes are associated with bone mineral density. J Mol Endocrinol 2009;42(3):239-47. doi: https://doi.org/10.1677/ JME-08-0108 [published Online First: 2009/01/10].

29. Seremak-Mrozikiewicz A, Drews K, Mrozikiewicz PM, et al. Correlation of vitamin D receptor gene (VDR) polymorphism with osteoporotic changes in Polish postmenopausal women. Neuro Endocrinol Lett 2009;30(4):540-6. [published Online First: 2009/12/17].

30. Perez A, Ulla M, Garcia B, et al. Genotypes and clinical aspects associated with bone mineral density in Argentine postmenopausal women. J Bone Miner Metab 2008;26(4):358-65. doi: https://doi.org/10.1007/s00774-0070840-2 [published Online First: 2008/07/05].

31. Uysal AR, Sahin M, Gursoy A, et al. Vitamin D receptor gene polymorphism and osteoporosis in the Turkish population. Genet Test 2008;12(4):591-4. doi: https://doi.org/10.1089/gte.2008.0052 [published Online First: 2008/11/04].

32. Quevedo LI, Martinez BM, Castillo NM, et al. [Vitamin D receptor gene polymorphisms and risk of hip fracture in Chilean elderly women]. Rev Med Chil 2008;136(4):475-81. http://doi.org/10.4067/S0034-98872008000400008 [published Online First: 2008/09/05].

33. Wengreen $H$, Cutler DR, Munger $R$, et al. Vitamin $D$ receptor genotype and risk of osteoporotic hip fracture in elderly women of Utah: an effect modified by parity. Osteoporos Int 2006;17(8):1146-53. doi: https://doi.org/ 10.1007/s00198-006-0100-7 [published Online First: 2006/06/08].

34. Garnero P, Munoz F, Borel O, et al. Vitamin D receptor gene polymorphisms are associated with the risk of fractures in postmenopausal women, independently of bone mineral density. J Clin Endocrinol Metab 2005;90(8):4829-35. doi: https:// doi.org/10.1210/jc.2005-0364 [published Online First: 2005/05/12].

35. Mitra S, Desai M, Ikram Khatkhatay M. Vitamin D receptor gene polymorphisms and bone mineral density in postmenopausal Indian women. Maturitas 2006;55(1):27-35. doi: https://doi.org/10.1016/j.maturitas. 2006.01.003 [published Online First: 2006/02/09].

36. Duman BS, Tanakol R, Erensoy N, et al. Vitamin D receptor alleles, bone mineral density and turnover in postmenopausal osteoporotic and healthy women. Med Princ Pract 2004;13(5):260-6. doi: https://doi.org/10.1159/ 000079524 [published Online First: 2004/08/19]. 
37. Douroudis K, Tarassi K, loannidis G, et al. Association of vitamin D receptor gene polymorphisms with bone mineral density in postmenopausal women of Hellenic origin. Maturitas 2003;45(3):191-7. [published Online First: 2003/06/24].

38. Lisker $R$, Lopez MA, Jasqui $S$, et al. Association of vitamin $D$ receptor polymorphisms with osteoporosis in Mexican postmenopausal women. Hum Bio/ 2003;75(3):399-403. [published Online First: 2003/10/07].

39. Borjas-Fajardo L, Zambrano M, Fernandez E, et al. [Analysis of Bsm I polymorphism of the vitamin $D$ receptor (VDR) gene in Venezuelan female patients living in the state of Zulia with osteoporosis]. Invest Clin 2003;44(4): 275-82. [published Online First: 2004/01/20].

40. Zajickova K, Zofkova I, Bahbouh $\mathrm{R}$, et al. Vitamin D receptor gene polymorphisms, bone mineral density and bone turnover: Fokl genotype is related to postmenopausal bone mass. Physiol Res 2002;51(5):501-9. [published Online First: 2002/12/10].

41. Pollak RD, Blumenfeld A, Bejarano-Achache I, et al. The Bsml vitamin D receptor gene polymorphism in Israeli populations and in perimenopausal and osteoporotic Ashkenazi women. Am J Nephrol 2001;21(3):185-8. doi: https://doi.org/10.1159/000046245 [published Online First: 2001/06/26].

42. Valimaki S, Tahtela R, Kainulainen $\mathrm{K}$, et al. Relation of collagen type I alpha 1 (COLIA 1) and vitamin D receptor genotypes to bone mass, turnover, and fractures in early postmenopausal women and to hip fractures in elderly people. Eur J Intern Med 2001;12(1):48-56. doi: https://doi.org/10.1016/ s0953-6205(00)00137-0 [published Online First: 2001/02/15].

43. Aerssens J, Dequeker J, Peeters J, et al. Polymorphisms of the VDR, ER and COLIA1 genes and osteoporotic hip fracture in elderly postmenopausal women. Osteoporos Int 2000;11(7):583-91. doi: https://doi.org/10.1007/ s001980070079 [published Online First: 2000/11/09].

44. Fontova Garrofe R, Gutierrez Fornes C, Broch Montane M, et al. [Polymorphism of the gene for vitamin $\mathrm{D}$ receptor, bone mass, and bone turnover in women with postmenopausal osteoporosis]. Rev Clin Esp 2000; 200(4):198-202. [published Online First: 2000/06/17].

45. Gomez C, Naves ML, Barrios Y, et al. Vitamin D receptor gene polymorphisms, bone mass, bone loss and prevalence of vertebral fracture: differences in postmenopausal women and men. Osteoporos Int 1999;10(3):175-82. doi: https://doi.org/10.1007/s001980050213 [published Online First: 1999/10/20]

46. Gennari L, Becherini L, Masi L, et al. Vitamin D and estrogen receptor allelic variants in Italian postmenopausal women: evidence of multiple gene contribution to bone mineral density. J Clin Endocrinol Metab 1998;83(3):939-44. doi: https://doi.org/10.1210/jcem.83.3.4649 [published Online First: 1998/03/20].

47. Zhu MJ, D. YX, F. W. Relationship between vitamin D receptor genotypes and bone mineral density in Guangxi Zhuang and Han nationality postmenopausal women. Chinese Journal of Osteoporosis 2004;2004-02.

48. Chen J, Zhang LP, Qiu JF, et al. The relationship between VDR gene polymorphism and PMOP in Chongqin area. Chin J Med Genet. 2003;20:2.

49. Leng XW, Chen RY, LY A, et al. Relationship between vitamin D receptor gene alleles and bone mineral density in women from Urumqi. Chin J Endocrinol Metab 2002;18(2):1. [published Online First: 213].

50. Ly A, Leng XJ, Chen RY, et al. Association of vitamin D receptor gene polymorphisms with bone mineral density in Uighurs in China. Health Care Med Chin PLA 2002;1:2. [published Online First: 42].

51. Zhang QX, Wang WJ, Kuang JQ, et al. Relationship between the polymorphism of vitamin D receptor gene and bone mineral density in preand postmenopausal women. Acad J SUMS 2000(5):4. doi: https://doi.org/ 10.13471/j.cnki [published Online First: 379].

52. Zhang HH, Tao GQ, Wu Q, et al. Preliminary studies on the relationship between vitamin $D$ receptor gene polymorphism and osteoporosis in Chinese women. Chin J Epidemiology. 1998;19:3.

53. Yanagi H, Tomura S, Kawanami K, et al. Vitamin D receptor gene polymorphisms are associated with osteoporosis in Japanese women. J Clin Endocrinol Metab 1996;81(11):4179-81. doi: https://doi.org/10.1210/jcem.81. 11.8923886 [published Online First: 1996/11/01].

54. Ramalho AC, Lazaretti-Castro M, Hauache $\mathrm{O}$, et al. Fractures of the proximal femur: correlation with vitamin D receptor gene polymorphism. Braz J Med Biol Res 1998;31(7):921-7. doi: https://doi.org/10.1590/s0100879x1998000700006 [published Online First: 1998/08/12]

55. Vandevyver C, Wylin T, Cassiman JJ, et al. Influence of the vitamin D receptor gene alleles on bone mineral density in postmenopausal and osteoporotic women. J Bone Miner Res 1997;12(2):241-7. doi: https://doi. org/10.1359/jbmr.1997.12.2.241 [published Online First: 1997/02/01].

56. Houston LA, Grant SF, Reid DM, et al. Vitamin D receptor polymorphism, bone mineral density, and osteoporotic vertebral fracture: studies in a UK population. Bone 1996;18(3):249-52. [published Online First: 1996/03/01].
57. Zhang L, Yin X, Wang J, et al. Associations between VDR gene polymorphisms and osteoporosis risk and bone mineral density in postmenopausal women: a systematic review and meta-analysis. Sci Rep 2018;8(1):981. doi: https:/doi.org/ 10.1038/s41598-017-18670-7 [published Online First: 2018/01/19].

58. Shen $\mathrm{H}$, Xie J, Lu H. Vitamin D receptor gene and risk of fracture in postmenopausal women: a meta-analysis. Climacteric 2014;17(4):319-24. doi: https://doi.org/10.3109/13697137.2013.856401 [published Online First: 2013/10/26].

59. Wang $D$, Liu $R$, Zhu $H$, et al. Vitamin D receptor Fok I polymorphism is associated with low bone mineral density in postmenopausal women: a meta-analysis focused on populations in Asian countries. Eur J Obstet Gynecol Reprod Biol 2013;169(2):380-6. doi: https://doi.org/10.1016/j.ejogrb. 2013.03.031 [published Online First: 2013/05/08]

60. Conti V, Russomanno G, Corbi G, et al. A polymorphism at the translation start site of the vitamin $D$ receptor gene is associated with the response to anti-osteoporotic therapy in postmenopausal women from southern Italy. Int J Mol Sci 2015;16(3):5452-66. doi: https://doi.org/10.3390/ijms16035452 [published Online First: 2015/03/13].

61. Yadav U, Kumar P, Rai V. Vitamin D receptor gene Fokl Bsml Apal and Taql polymorphisms and osteoporosis risk a meta analysis. Egypt J Med Hum Genet 2020;21(15) doi: https://doi.org/https://doi.org/10.1186/s43042-020-00057-5.

62. Mafi Golchin M, Heidari L, Ghaderian SM, et al. Osteoporosis: a silent disease with complex genetic contribution. J Genet Genomics 2016;43(2):49-61. doi: https://doi.org/10.1016/j.jgg.2015.12.001 [published Online First: 2016/03/01].

63. Mezquita-Raya P, Munoz-Torres M, Alonso G, et al. Susceptibility for postmenopausal osteoporosis: interaction between genetic, hormonal and lifestyle factors. Calcif Tissue Int 2004;75(5):373-9. doi: https://doi.org/10. 1007/s00223-004-0187-9 [published Online First: 2004/12/14].

64. Wang $\mathrm{S}, \mathrm{Ai} Z$, Song $\mathrm{M}$, et al. The association between vitamin $\mathrm{D}$ receptor Fokl gene polymorphism and osteoporosis in postmenopausal women: a meta-analysis. Climacteric 2020:1-6. doi: https://doi.org/10.1080/13697137. 2020.1775806 [published Online First: 2020/06/20].

\section{Publisher's Note}

Springer Nature remains neutral with regard to jurisdictional claims in published maps and institutional affiliations.

Ready to submit your research? Choose BMC and benefit from:

- fast, convenient online submission

- thorough peer review by experienced researchers in your field

- rapid publication on acceptance

- support for research data, including large and complex data types

- gold Open Access which fosters wider collaboration and increased citations

- maximum visibility for your research: over $100 \mathrm{M}$ website views per year

At $\mathrm{BMC}$, research is always in progress.

Learn more biomedcentral.com/submission 